\title{
Humanitært arbeid blant leger må anerkjennes
}

\author{
Helsedirektoratet jobber i disse dager med store endringer i spesialistutdanningen for leger. Leger Uten \\ Grenser vil oppfordre de ulike aktørene til å inkludere humanitært arbeid i de nye spesialistreglene. Huma- \\ nitært arbeid bør gjelde som tellende tjeneste, og spesialistreglene må legge til rette for at leger kan bidra \\ i felt.
}

Det er bred enighet om at det å jobbe som lege i humanitær tjeneste ikke bare er individuelt berikende, men også kompetansehevende for vårt eget helsevesen (1-3). Allikevel er det blitt med fine ord. Per i dag er det fortsatt nærmest umulig å få utenlandsarbeid godkjent som del av spesialiseringen. Legene som Leger Uten Grenser sender ut, får sjelden fri fra jobb for å dra på oppdrag. Utenlandstjeneste gir ingen tellende ansiennitet. Arbeidsgivere melder legene ut av pensjonskassen når de tar ulønnet permisjon, dermed mister de opptjent pensjonstid. Noen sykehus gir lønn i en måned, men dette gjelder de færreste, og reglene er ikke standardiserte.

Leger Uten Grenser sender hvert år ut omkring 20 leger fra Norge. Det er store udekkede behov der ute, og vi vil gjerne sende ut mange flere. Våre leger tjener lite - startlønnen ligger på ca. 15000 kroner i måneden - og de jobber mye og bor enkelt. Men når vi spør hva som hindrer dem i å reise ut på flere oppdrag, er ikke dårlig lønn, enkle levekår eller lang arbeidstid viktigste begrunnelse. De viktigste årsakene til at leger ikke reiser på flere oppdrag, er vanskeligheter med å få permisjon, at feltarbeid ikke gir ansiennitet ved ansettelser, og at felterfaringen ikke er tellende for spesialiseringen. Innen man er ferdig spesialist har de fleste stiftet familie og er ikke lenger fri til å reise ut.

For den enkelte lege er det ugunstig å velge humanitært arbeid: spesialiseringsløpet forlenges, man risikerer konflikt med ledere når man ønsker å ta permisjon, og ferien avkortes fordi man må bytte ferieuker for å være fleksibel på utreisedatoer. I stillingsannonser blir ikke humanitært arbeid sett på som en ressurs, slik forskningserfaring gjør. En lege som redder liv og er uunnværlig i en global verden, anses åpenbart ikke som en ressurs eller en berikelse for arbeidsgivere her hjemme.

\section{Strenge krav til kompetanse og sikkerhet}

Leger Uten Grenser stiller strenge krav til legens kompetanse i de enkelte spesialiteter, som anestesi, kirurgi og gynekologi, men man trenger ikke nødvendigvis være ferdig spesialist for å kunne jobbe innen fagfeltet sitt. Leger Uten Grensers legespesialistreferenter på hovedkontorene validerer hver enkelt lege ut fra vedkommendes erfaring, kompetanse og mestring av prosedyrer.

Pasientsikkerhet er minst like viktig i arbeid med sårbare befolkningsgrupper i felt som det er her hjemme. Leger Uten Grenser stiller med et grundig og profesjonelt apparat rundt legene som reiser ut, de blir ikke sendt ut uten oppfølging.

\section{Variert erfaring}

Våre leger jobber i mange forskjellige typer prosjekter - alt fra flyktningleirer, mobile team, vaksineringskampanjer og spesialist-

\section{«En lege som redder liv og er uunnværlig i en global verden, anses åpenbart ikke som en ressurs eller en berikelse for arbeids- givere her hjemme»}

tjeneste på store, avanserte sykehus omgitt av mange kolleger til ensomme stillinger på landsbygda med stort individuelt ansvar.

Mange av problemstillingene man møter i lavressursland er lik dem man møter i Norge, men omstendighetene er forskjellige. Man jobber tett med lokale team og medarbeidere og ser mange flere pasienter. Det gir innsikt i og trening i samhandling, konflikthåndtering og prioritering av knappe ressurser - kompetanse som lett kan overføres til arbeid i det norske helsevesenet. Unge leger som reiser ut, får kunnskap om patologier, kulturer, helsesystemer, ledelse og organisering som man ikke får ved å jobbe som lege i spesialisering i Norge.

De fleste som reiser ut, har et genuint ønske om å hjelpe, men de ønsker også å være med på å endre systemer og utvikle tjenester der det trengs mest. Slikt engasjement og nysgjerrighet er gull verdt, både der ute og her hjemme.

\section{Feltarbeid må telle}

Leger Uten Grenser har lenge arbeidet for å få humanitært feltarbeid tellende som tjeneste i spesialiseringen. Vi ønsker at de enkelte spesialistkomiteene forankrer humanitært arbeid i sine spesifikke læringsmål og i regelverket.
Supervisjon og læringsmål er viktige punkter i de nye reglene. Dette er områder der vi ser at det kunne la seg gjøre å lage et gjennomførbart opplegg som dekker kravet til kvalitet $\mathrm{i}$ utdanningen når man er uten i felt. For eksempel kan en lege i spesialisering på utenlandsoppdrag beholde sin sykehusveileder i Norge, som sammen med Leger Uten Grenser kan følge opp vedkommende, for eksempel via Skype.

Om det ikke legges til rette for å jobbe humanitært utenfor ressurssterke land, og om verdien av dette ikke anerkjennes, går det norske helsevesenet glipp av verdifull kompetanse. I dag blir leger motarbeidet når de ønsker å utføre humanitært arbeid. I stedet bør slik innsats bejubles.

\section{Monica Thallinger}

thallingermonica@hotmail.com

Monica Thallinger (f. 1979) er barnelege og jobber for Leger Uten Grenser og ved Oslo universitetssykehus, Rikshospitalet. Hun er ph.d.-stipendiat ved Institutt for klinisk medisin, Universitetet i Oslo, og styremedlem i Leger Uten

Grenser, Norge.

Forfatter har fylt ut ICMJE-skjemaet og oppgir ingen interessekonflikter.

Litteratur

1. Flaatten K. Humanitært arbeid må telle. Tidsskr Nor Legeforen 2011; 131: 337.

2. Engjom H. Norske leger og humanitært arbeid. Tidsskr Nor Legeforen 2011; 131: 1743-4.

3. Kristiansen TH. Flere omkostninger ved humanitært arbeid. Tidsskr Nor Legeforen 2011; 131: 801-2.

Mottatt 13.7. 2016, første revisjon innsendt 5.8. 2016, godkjent 8.8. 2016. Redaktør: Ketil Slagstad.

Publisert først på nett. 